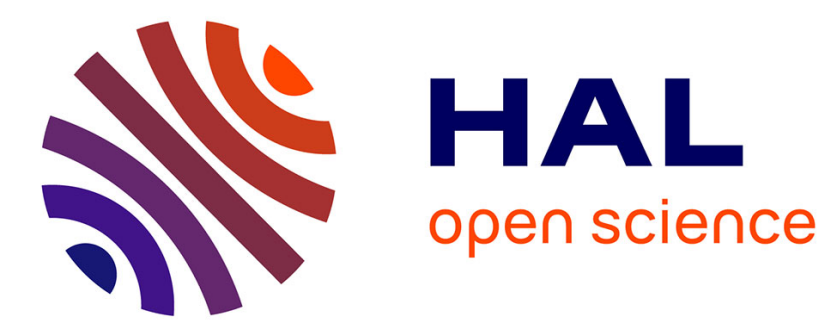

\title{
Guardianship for crime prevention: a critical review of the literature
}

\author{
Meghan E. Hollis-Peel, Danielle M. Reynald, Maud Bavel, Henk Elffers, \\ Brandon C. Welsh
}

\section{- To cite this version:}

Meghan E. Hollis-Peel, Danielle M. Reynald, Maud Bavel, Henk Elffers, Brandon C. Welsh. Guardianship for crime prevention: a critical review of the literature. Crime, Law and Social Change, 2011, 56 (1), pp.53-70. 10.1007/s10611-011-9309-2 . hal-00701727

\section{HAL Id: hal-00701727 https://hal.science/hal-00701727}

Submitted on 26 May 2012

HAL is a multi-disciplinary open access archive for the deposit and dissemination of scientific research documents, whether they are published or not. The documents may come from teaching and research institutions in France or abroad, or from public or private research centers.
L'archive ouverte pluridisciplinaire HAL, est destinée au dépôt et à la diffusion de documents scientifiques de niveau recherche, publiés ou non, émanant des établissements d'enseignement et de recherche français ou étrangers, des laboratoires publics ou privés. 
Guardianship for Crime Prevention: A Critical Review of the Literature

\author{
Meghan E. Hollis-Peel \\ Northeastern University and
}

Netherlands Institute for the Study of Crime and Law Enforcement

Danielle M. Reynald

Griffith University

\begin{abstract}
Maud van Bavel
Netherlands Institute for the Study of Crime and Law Enforcement and VU University Amsterdam
\end{abstract}

Henk Elffers

Netherlands Institute for the Study of Crime and Law Enforcement and VU University Amsterdam

\author{
Brandon C. Welsh* \\ Northeastern University and
}

Netherlands Institute for the Study of Crime and Law Enforcement

* Corresponding author. School of Criminology and Criminal Justice, Northeastern University, Boston MA 02115; e-mail: b.welsh@neu.edu 


\begin{abstract}
Cohen and Felson's [7] routine activity theory posits that for a crime to occur three necessary elements must converge in time and space: motivated offenders, suitable targets, and the absence of capable guardianship. Capable guardians can serve as a key actor in the crime event model; one who can disrupt, either directly or indirectly, the interaction between a motivated offender and a suitable target. This article critically reviews the literature on guardianship for crime prevention. Our specific focus is twofold: (1) to review the way guardianship has been operationalized and measured, and (2) to review experimental and quasi-experimental evaluations and field tests of guardianship. Research on routine activities has had an uneven focus resulting in the neglect of the guardianship component $[36,39,48,57]$. Evaluations of guardianshiprelated interventions demonstrate support for the theoretical construct; however, highquality field tests of guardianship are wholly lacking. Implications for theory and research are discussed.
\end{abstract}

Keywords: routine activity theory, guardianship, crime prevention, experimental research 
Routine activity theory [7] was developed at a time when almost all criminological theories and research focused on the etiology of crime (the motivation of offenders) or characteristics of individuals who commit crimes. Cohen and Felson (in: [7]: 589) noted: "Unlike many criminological inquiries, we do not examine why individuals or groups are inclined criminally, but rather we take criminal inclination as given and examine the manner in which the spatio-temporal organization of social activities helps people to translate their criminal inclinations into action." The theory posits that for a criminal event to occur three elements must converge in time and space: (1) a likely or motivated offender, (2) a suitable target, and (3) the absence of capable guardianship. Routine activities are defined as "recurrent and prevalent activities which provide for basic population and individual needs, whatever their biological or cultural origins" (in: [7]: 593). Routine activities might include activities that occur at home, work, or any other place, but that are defined by a person's daily routines.

The three elements of routine activity theory have been the subject of previous research, although the research has had an uneven focus. Many tests have been carried out - covering a wide range of theories - on the motivation of the offender (etiological and opportunity approaches; e.g., $[19,41])$. Similarly, many tests have been conducted on target suitability (victimological and situational or environmental approaches; e.g., [6, 22]). Unlike the other two dimensions of this theory, there is no equivalent of "guardianology" as a thorough examination of capable guardianship. Sampson et al. [39] emphasize this major gap in the routine activities literature stating that there is not enough work on preventive actions of people and organizations (see also [5, 25, 27]). 
This article focuses on human guardianship. This focus is in line with the original conception of guardianship and subsequent work (see e.g., [13]). We define guardianship as the physical or symbolic presence of an individual (or group of individuals) that acts (either intentionally or unintentionally) to deter a potential criminal event. This follows Felson's description of guardianship as any person who "serves by simple presence to prevent crime and by absence to make crime more likely" (in: [11]: 53). As an example, we include the use of closed-circuit television (CCTV) cameras as human guardianship only when it is actively monitored. This is based on the notion that a camera implants the suggestion that a guardian is somewhere behind it, invisible perhaps but nevertheless present. This is seen by the offender as a sign that there is someone watching - one of the essential elements of engaging in guardianship activities.

This is a departure from some other research, as we find the notion of guardians as having a goal of protecting targets too limited. Guardians may engage in guardianship activities unintentionally or unknowingly. It is often the simple presence of an individual that serves to prevent the crime from being carried out - and it is this notion of guardianship that we find most useful and appealing for the purposes of this article.

The main aim of this article is to critically review the most up-to-date literature on guardianship. Our specific focus is two-fold: (1) to review the way guardianship has been operationalized and measured, and (2) to review experimental and quasiexperimental evaluations and field tests of guardianship. Our focus on experimental and quasi-experimental methods is not meant to diminish the contributions of other research. Rather, at a time of increased interest in experimental criminology (for contrasting views, 
see $[40,53])$, we are particularly interested in their contribution to guardianship studies, something that has not yet been examined in any sufficient detail.

\section{DEFINING AND MEASURING GUARDIANSHIP}

The guardianship concept has been defined and measured in several different ways and has evolved over time as a result. Guardianship has also been tested in a variety of ways - both through tests of theoretical propositions and evaluations of interventions derived from routine activity theory.

\section{Defining Guardianship}

The evolution of the original theorists' definition of guardianship can be traced. Originally, Cohen and Felson [7] indicated that although guardianship is a common occurrence in everyday life, it is best seen where criminal violations are absent, making it uncommon to observe and study. They stated, "While police action is analyzed widely, guardianship by ordinary citizens of one another and of property as they go about routine activities may be one of the most neglected elements in sociological research on crime, especially since it links seemingly unrelated social roles and relationships to the occurrence or absence of illegal acts" (in: [7]: 590). What is meant by the term guardianship was not clearly defined in their seminal article, other than to note the important supervisory functions guardians carry out in the course of their routine daily activities.

Felson revisited the guardianship concept in later works $[11,12,13]$. He defined the role of a guardian as follows: "A guardian keeps an eye on the potential target of 
crime. This includes anybody passing by, or anybody assigned to look after people or property. This usually refers to ordinary citizens, not police or private guards... Usually we think of guardians as looking after specific persons and property that could be targeted" (in: [12]: 80, emphasis in original). The fundamental assumption underlying Felson's work is that the most important tasks for guardians are availability and monitoring. It is the idea that someone is watching and could detect untoward behaviors that deters the likely offender from committing a criminal act.

The most recent and extensive discussion of the guardianship definition appears in Felson's latest work whereby he defines guardianship as "someone whose mere presence serves as a gentle reminder that someone is looking" or those who engage in natural surveillance, including "ordinary citizens going about their daily lives but providing by their presence some degree of security" (in: [13]: 28, 37). He further clarifies the guardianship concept, stating “'Guardians” should not be mistaken for police officers or security guards who are very unlikely to be on the spot when a crime occurs" (in: [13]: 28).

Other research has broken down guardianship into three subtypes that are often referred to as "controllers:” handlers, managers, and guardians [10, 11, 13, 39, 50]. Handlers are supervisors of potential offenders or "people with whom offenders have an emotional attachment...[whose] goal is to keep possible offenders out of trouble" (in: [39]: 39), such as parents, schoolteachers, or employers. Managers are supervisors of potential settings for criminal events (or places) "whose presence and alertness discourages crime from happening there" (in: [13]: 30). Sampson et al. (in: [39]: 39) describe managers as "the owners of places, or the owners' representatives at the 
place...[whose] goal is the smooth functioning of the place." As mentioned previously, Felson [12] defines a guardian as that person who keeps an eye on the potential target of crime, whether that is an object or a person. Sampson et al. (in: [39]: 39) describe guardians as having "the goal of protecting targets" and indicate that "guardians are highly varied." The three are interrelated in their influence on whether or not a crime is completed: "the offender moves away from handlers toward a place without a manager and a target without a guardian" (in: [13]: 30).

The original crime event triangle can be seen as having the three necessary elements: suitable target, motivated offender, and lack of capable guardianship, with each coming together in time and space to produce a criminal event. Eck [10; see also: 11] revised this view of the crime event and the triangle to depict each of the sides of the triangle as representing the target of crime, the offender, and the place where a crime occurs. This demonstrated that the offender and crime target have to come together in a suitable place for a crime event. Outside of this in the second layer of the triangle, Eck showed the controllers who control each of these elements - those who can reduce the likelihood of a crime event by controlling one of the three elements and engaging in preventive action. In this depiction, the handler is looking over the offender, the place manager is looking over the criminogenic place, and the guardian is watching the target.

Felson highlights that place managers and handlers are types of guardians, but despite the existence of other categories of guardianship, place managers might play the most important role of the three. This is not to diminish the importance of handlerguardians and target-guardians; indeed place managers "cannot watch everything everywhere" (in: [13]: 37). Sampson et al. (in: [39]: 40) ask, "Why are some controllers 
ineffective? Or, why do they sometimes fail to take appropriate action?" They determine that the incentive to take appropriate action and be an effective controller is supplied by what they refer to as 'super-controllers.' A full discussion of super-controllers is outside of the scope of this article.

For the purposes of this article, the concept and definition of guardians, handlers, and managers are too limited in the sense that all of these people have (in some way) an existing "commitment" to a special person, place, or target. This conceptualization (where guardians are only those with the goal of target protection) neglects the occasional guardian (the most important guardian-type, in our opinion), or those who are simply at or near the scene of a potential criminal event. It is this individual (or group of individuals) who, often even unknown to themselves, is preventing the criminal event then and there. A standard example of this is the passer-by who by mere presence deters the motivated offender from stealing a bicycle even though the passer-by did not know a crime was about to be committed. The mechanism through which these occasional guardians operate is by being "on the scene" of the potential criminal event providing a possibility that the crime will be noted and an intervention (whether by directly approaching the offender or indirectly through bringing the crime to the attention of a police officer or security guard) will occur. It is not necessary that the guardian feels any responsibility beforehand or actively seeks to prevent criminal activities.

Moreover, even when the potential guardian has no intention at all to exercise guardianship, he is already acting in a passive way as a guardian by mere presence. It is this conceptualization of guardianship that is most fitting, as there are usually many more haphazard individuals on a scene than there are formal handlers, place managers, or 
intentional target guardians. We propose a formal definition that is in line with the work of Reynald [36], whereby a guardian is any person and every person on the scene of a potential crime that may notice and intervene (whether they intend to or not). This definition includes the formal guardians, handlers, managers, and target-guardians that have been discussed here.

\section{Measuring Guardianship}

The highly divergent conceptualizations of guardianship discussed above result in an even greater variety of operationalizations of the concept. The original conceptualization and test of the theory involved a macro-structural approach [7, 14]. While some researchers have followed in this tradition of using aggregate data to test the theory, others have applied a micro-level or place-based approach. These approaches change the manner in which guardianship has been operationalized and measured in research as well as the research designs utilized.

Stahura and Sloan [46] measured guardianship through three variables: police employment, police expenditure, and female labor force nonparticipation. Miethe and Meier [31] operationalized guardianship as living with another household member over the age of 16. Miethe et al. [30] operationalized guardianship as household occupancy based on the number of persons in the household over the age of 12. Garofalo and Clark [16] asked household members how often they were home and incorporated proxy measures of guardianship including presence of a dog, presence of an alarm system, and other related measures. The use of measures such as presence of a dog or a security system are outside the purview of the conceptualization of guardianship in terms of 
human surveillance. Furthermore, the reliance on proxy measures and indicators is problematic in developing a thorough understanding of how the guardianship process operates [36]. The use of these proxy measures can be questioned on the grounds of the lack of knowledge and understanding. This is particularly true regarding knowledge about when victimizations are occurring, such as when potential guardians are not home, unavailable, or otherwise not monitoring. There is no way of knowing if there is a direct causal relationship (between guardian availability/monitoring and prevention of a criminal event), or if some other event may have caused the prevention (or occurrence) of a criminal event, without direct observation and measurement.

Other research operationalizes guardianship through increased use of target hardening measures. For example, Mustaine and Tewksbury (in: [33]: 834) operationalized guardianship as "the degree of protection afforded to property or persons" and measured it by collecting information on the use of self-protective behaviors by individuals, including weapon possession and possession of body alarms or mace (see also [48]). There is some debate surrounding the use of these measures. Some researchers find that the extent to which personal protection measures (such as selfprotective behaviors, possessing weapons, and use of body alarms and mace or pepper spray) are synonymous with guardianship is lacking (see e.g., [4, 57]). They find that these do not measure attempts at controlling behaviors on the part of guardians. Variables such as self-protective and personal protective behaviors instead measure target hardening. Confusion surrounding differentiating between target suitability and capable guardianship continues in research that measures guardianship through target hardening measures (certain situational crime prevention measures) - such as utilizing alarm 
systems, locks, and signs (e.g., [16, 31, 51, 57]). Target hardening and capable guardianship are conceptually distinct. Guardianship is exercised by individuals who deter potential criminal acts by watching over potential targets of criminal activity while target hardening is decreasing the suitability of the target for crime by making changes to the targets (whether these are people, places, or objects) to make them less attractive to the potential offender.

Coupe and Blake [8] measured guardianship through the use of security devices, whether or not the burglar was spotted, and whether the household was occupied at the time of the burglary. The concern with this study is that it only used reported cases of burglary and there were no households included that did not experience burglaries to examine the influence of guardianship on crime outcomes. Wilcox et al. [57] measured guardianship through individual-level target hardening, place management, and surveillance measures and neighborhood-level target hardening, informal social control, and natural surveillance measures.

Reynald $[36,37]$ takes a different approach to the operationalization of guardianship. She demonstrates that capable guardianship requires monitoring and intervention when necessary, while availability arguably remains the most critical dimension as articulated by Cohen and Felson [7] and Felson [12, 13]. Reynald [36, 37] measured guardianship through an action-based, observational approach that suggested that availability, supervision, and intervention by guardians are directly observable, which provides a more ecologically valid measure than the aforementioned proxy measures from previous research. This action-based measure breaks down guardianship 
into three cumulative stages: (1) availability, (2) supervision and monitoring activities, and (3) intervention when necessary.

The methods used to study guardianship vary as greatly as the operationalization and measurement of the concept, and range from macro-structural to survey to observational approaches. Stahura and Sloan [46] used macro-structural data to look at both aggregated cross-sectional correlations between guardianship and crime and changes over time in aggregated levels of guardianship and crime. Garofalo and Clark [16] used cross-sectional survey research methodologies in which household surveys were collected in the study area. Miethe et al. [30] utilized a panel study design with data collected at two separate time points, allowing them to analyze changes in both household size and criminal victimization. Tewksbury and Mustaine [48] utilized crosssectional and self-administered surveys of college students. Wilcox et al. [57] used cross-sectional neighborhood surveys. Reynald [36, 37] utilized a fieldwork oriented, action-based, and observational data collection tool to examine guardianship in action (GIA). Her operationalization and research design come closest to what we argue is the preferred conceptualization of guardianship within the framework of this article. The heavy reliance on cross-sectional and non-observational data with no control conditions and the use of mostly proxy-based measures stands out in these studies. Experimental tests of the theoretical construct of guardianship are wholly lacking.

\section{Effect of Guardianship on Crime}

Prior tests of routine activity theory have mostly found significant desirable effects of guardianship on crime. Table 1 summarizes the key characteristics and 
findings of studies that have investigated the effects of guardianship on crime. Cohen and Felson [7] found that increased levels of guardianship are related to significantly lower levels of crime. Coupe and Blake [8] found that guardianship operated conditionally on whether it was daylight or dark outside (though their study was not designed to examine the relationship between guardianship levels and crime specifically). Lynch and Cantor [28] found that guardianship at the block level has a significant effect on burglary risk. They also found that measures of daytime occupancy had a significant effect on crime while nighttime occupancy did not. Miethe et al. [30] found that proximity and exposure were stronger predictors than guardianship and design attractiveness. Tewksbury and Mustaine [48] did not examine the influence of guardianship on crime, but instead examined the influences on choices to use selfprotective behaviors such as proximity to offenders and prior victimization. Wilcox et al. [57] found that, at the individual level, target hardening, place management and surveillance were related more negatively to burglary rates when neighborhood-level target hardening, natural surveillance, and informal social control increased.

[Table 1 about here]

\section{EVALUATIONS AND FIELD TESTS OF GUARDIANSHIP}

Methods

Two main search strategies were employed to locate evaluation studies of human guardianship interventions that have utilized experimental or quasi-experimental designs. The first involved searches of systematic reviews of the literature. These reviews use 
rigorous methods for locating, appraising, and synthesizing evidence from prior evaluation studies. They are an especially good source of high quality evaluation designs on a specific intervention topic. One source for these reviews is the Campbell Collaboration's library of crime and justice systematic reviews. At the time of our search the library had 25 published reviews, with well over 1,000 evaluation studies. Other known repositories of systematic reviews, including the Swedish National Council for Crime Prevention and the U.S. National Institute of Justice, were also searched.

The systematic reviews that were relevant to our focus on guardianship used a common set of criteria to determine which studies should be included. One criterion was that there was an outcome measure of crime. Another criterion was that the evaluation design was of high methodological quality, with the minimum design involving beforeand-after measures of crime in experimental and comparable control areas. Another important criterion was that the total number of crimes in each area before the intervention was at least 20. It was determined that any study with fewer than 20 crimes before would have insufficient statistical power to detect changes in crime.

To locate studies meeting these criteria, the systematic reviews also used a common set of strategies, including searches of electronic bibliographic databases, searches of reviews of the literature, searches of bibliographies of evaluation reports of applicable studies, and contacts with leading researchers. Both published and unpublished reports were considered in the searches. Search terms were specific to the type of intervention. For example, for security guards, the following terms were used: security guards, private police, formal surveillance, and guardian. (For more details on 
the inclusion criteria and search strategies, see $[3,55]$.) These searches of systematic reviews yielded 62 studies.

The second search strategy involved targeted searches of the published literature. This was carried out in an effort to identify any new studies since the publication of the systematic reviews. The same inclusion criteria were used. This was not as exhaustive as the systematic reviews, as resources did not permit a comprehensive update of these reviews. We were, however, able to examine many of the same databases and conduct manual searches of leading criminology journals. This search strategy yielded only one new study. A similarly targeted search strategy was employed to locate experimental and quasi-experimental field tests of guardianship.

\section{Evaluations}

Five main types of human guardianship have been evaluated with experimental and quasi-experimental designs: security guards, urban citizen patrols, place managers, actively monitored closed-circuit television (CCTV) surveillance cameras, and neighborhood watch. It is important to note that not one of these five research lines addresses the unintentional guardianship concept that was discussed above. Each looks at formal, dedicated guardianship of different degrees of linkage to formal law enforcement. We revisit this key point in the concluding section of the article.

Most evaluations of guardianship programs are called area-based studies. In these studies, the effect of crime on the area or place (e.g., town center, public housing estate, car park) is measured, rather than the effect of crime on the individual, which is assessed in commonly used evaluation studies. In area-based studies, the best and most feasible 
design usually involves before-and-after measures of crime in experimental and comparable control conditions, together with statistical control of extraneous variables. This is an example of a quasi-experimental evaluation design. Almost all of the evaluations of the different methods of guardianship reviewed here used this type of design or a close approximation. Selected studies are discussed in more detail, focusing on the operationalization of guardianship.

Security Guards. Security guards are often referred to as private police and can be considered as exercising formal guardianship. Security guards are different from police in that they are typically unarmed, lack arrest powers, and are cautious to avoid the appearance of taking on police officer responsibilities [45]. Security guards perform a range of functions, including protecting individuals and property and warning people about inappropriate or unacceptable behaviors. Security guards are available, monitoring, and expected to intervene.

Five high-quality studies have evaluated the effects of security guards on crime (see [56]). Two of these studies were carried out in the United Kingdom and the others were carried out in the Netherlands, Canada, and the United States. Three of the studies were carried out in car parks and two in retail establishments. There is difficulty in assessing the effectiveness of security guards based on these small numbers. The authors concluded that this might be a promising technique of formal surveillance when it is implemented in car parks and when it is used to specifically target vehicle crimes.

In Vancouver, Canada, formal guardianship in the form of bicycle-mounted security guard patrols were introduced in the largest "park-and-ride" commuter car park 
to address increased rates of vehicle thefts [2]. An analysis of the layout of the parking lot and surrounding area revealed that there was poor visibility into the car park as well as a lack of nearby shops or other establishments with a regular flow of pedestrians who might perform a guardianship function. The implementation of the security guard patrols, which lasted only one month, was preceded by a media campaign. Three months after the program ended, there was a significant reduction in the rate of vehicle thefts with little or no displacement.

Hesseling [21] examined the effects of the use of security guards in a number of car parks in Rotterdam's inner city. The security guard scheme was implemented in 1992 and lasted four years. The main focus of the intervention was increased surveillance at 10 hot spots. The security guards wore the same uniforms as police officers and had full police powers, but did not carry firearms. They patrolled the car parks - often in pairs to monitor potential targets for victimization and would also issue written warnings to those who engaged in risky behaviors, such as leaving their vehicles unlocked or leaving valuables in sight in the car. There was no change in thefts from vehicles, and evidence of displacement was demonstrated in four of the five control areas. From interviews with offenders and an analysis of the deployment of the security patrols, Hesseling [21] concluded that the scheme was not intense enough to deal with the volume of motivated offenders.

Urban Citizen Patrols. Like their security guard counterparts, urban citizen patrols are also an example of formal guardianship. Citizen dissatisfaction with the police response to escalating crime problems is often the main reason for the 
development of these groups. The best-known group is the Guardian Angels. It is also the only known urban citizen patrol group that has been rigorously evaluated to assess its impact on crime.

Two evaluations of the Guardian Angels took place in New York City and San Diego in the mid-1980s. Kenney [24] found that they had no appreciable effect on crime in New York City's subway system; however, the overall small number of criminal incidents that occurred on the subway impeded the evaluation. In New York City, the Guardian Angels engaged in routine patrols in problematic subway stations. This group included citizen volunteers who rode the subway system to deter crime through a simple presence. Pennell et al. [34] found that the introduction of Guardian Angels patrols in a downtown redevelopment area of San Diego was effective in reducing property crime but had no effect on violent crime. This study faced contamination problems because police foot patrols were introduced in the experimental area at the same time as the Guardian Angels patrols.

Place Managers. Place managers are persons such as bus drivers, parking lot attendants, train conductors, and others who perform a guardianship function by virtue of their position of employment. Unlike security guards and citizen patrols, however, the task of guardianship for these employees is secondary to other job duties. In the case of parking lot attendants, for example, they are first and foremost responsible for parking and retrieving vehicles for customers and collecting money for this service. The secondary guardianship function they perform comes about from their presence, monitoring of the place, and ability to intervene. 
Only three high-quality studies were found that assessed the effects of place managers on crime (see [56]). All of the studies are several years old. Two were carried out in the U.K. and the other in the Netherlands. Only two were adequate for the systematic review. Because of the small number of studies the authors were left to conclude that place managers are of unknown effectiveness at this time.

Poyner [35] operationalized place managers as a taxi company operating out of a multi-level, high-crime (mostly thefts of and from vehicles) parking garage in Dover. An office was constructed near the entrance to the garage, which was then leased to a taxi company that was open most hours on the weekend and from 8:00 to 24:00 on weekdays. It was hypothesized that the presence of the taxi company would reduce crime levels in the garage. Two years after implementation, police-reported vehicle crimes were down by half in both the experimental (50\%) and control (49\%) areas. It is difficult to say whether this scheme was indeed effective, because the author did not investigate whether the control area's reduction in vehicle crime resulted from a diffusion of benefits from the targeted site.

Van Andel [52] evaluated an innovative place manager scheme in the public transit systems in Amsterdam, Rotterdam, and The Hague. Place managers were 1,140 unemployed young people (ages 19-28) hired to serve as VICs (in English, meaning "safety, information and control" officers). Their duties were to reduce fare dodging, vandalism, and aggressive behavior, and to improve the information and service available to passengers. VICs received two to three months of legal and practical training prior to their deployment. The VIC scheme was applied differently in each of the three cities. For example, in Amsterdam they were authorized to levy fines and carry out random 
checks on trams and the metro, operating in groups of two to four. A slight reduction in the repair costs of vandalism to the three modes of transport (tram, metro, and bus) was observed in Amsterdam in the first year following deployment of the VICs, but not within the metro station. Across-the-board reductions in the percentage of fare dodgers were realized in all three cities.

Actively Monitored CCTV. CCTV surveillance cameras serve many functions, including preventing crime, aiding police in the detection and apprehension of suspects, detecting and preventing terrorism, and improving police officer safety and compliance with the law. Active monitoring means that an operator watches monitors linked to CCTV cameras in real time. Conversely, passive monitoring involves watching recordings of camera footage at a later time. The operators of actively monitored systems, often police or security personnel, are considered formal guardians. They are available, monitoring, and able to intervene albeit sometimes indirectly.

Welsh and Farrington ([54]; see also [55]) carried out a systematic review of the effects of CCTV on crime in public space. Of the 44 included studies (all with quasiexperimental designs), 34 used active monitoring. Active monitoring was carried out by police, security personnel, residents of an apartment building, and transit police. Thirty of these studies were carried out in the U.K., three in the U.S., and one each in Canada and Norway. Fifteen studies were carried out in city and town centers, nine in public housing, five in car parks, four in public transport, and one each in a residential area and a hospital. Although Welsh and Farrington [54] did not assess the effectiveness of CCTV 
by active versus passive monitoring, a review of the studies shows that active monitoring demonstrates promise.

Winge and Knutsson [58] evaluated a CCTV scheme in Oslo, Norway, outside of the central railway station. Six cameras were actively monitored by a specially trained group of public transport officials with a direct link to the Oslo police, allowing dispatch to monitor events at the police headquarters facility. The monitoring took place in an operations room near the railway station. Results of the scheme were mixed, with a reduction in robbery/theft from persons, no change in bicycle theft, and an overall significant increase in recorded incidents in the monitored area compared to the control area, possibly indicating increased detection.

Gill and Spriggs [18] evaluated an actively-monitored CCTV scheme in a public housing area in the United Kingdom. The cameras were actively monitored by security personnel. The security personnel had a communication link to the police via either a one-way or two-way radio. Results of the scheme indicated a reduction in crime with no evidence of displacement.

Neighborhood Watch. Neighborhood watch is a form of residential guardianship that developed in the 1960s in the U.S. in an effort to increase citizen involvement in crime prevention [3]. Neighborhood watch has also been referred to as block watch, apartment watch, home watch, and community watch. It relies on two primary mechanisms to reduce criminal activity: (1) increasing active guardianship and intervention on the part of residents, and (2) reducing criminal opportunities (by creating an image of occupancy). It is often introduced as part of a package of crime prevention 
measures. Theoretically, guardians involved in neighborhood watch are increasingly available (or give that appearance), more likely to be monitoring, and increasingly likely to intervene.

Bennett et al. [3] carried out a systematic review of neighborhood watch, which included 18 high-quality studies. They found that this form of guardianship was associated with a $16 \%$ reduction in crime in communities where it was implemented compared to similar communities that did not receive it. Further analyses showed that there was no difference in effectiveness between programs based on neighborhood watch alone and those that also included property marking and security marking and security surveys carried out by the police. Interestingly, no difference was found in the effectiveness of neighborhood watch programs over time, that is, the first generation of programs evaluated in the 1970s and 1980s were just as effective as their more modern counterparts that were evaluated in the 1990s.

Tilley and Webb [49] evaluated a neighborhood watch scheme in several British communities, as part of the Safer Cities Program. The manner in which neighborhood watch was implemented differed across sites. Target hardening was incorporated at each site with a common goal of bringing physical security of homes up to a minimum acceptable standard; however, its content and delivery varied. Two of the sites also incorporated property marking. At each site a project worker was tasked with developing and implementing neighborhood watch schemes. Home watch coordinators were responsible for visiting new tenants and property marking at one site. A significant reduction in residential burglary rates was observed at all three sites. 
Field Tests

Experimental and quasi-experimental research on guardianship could come in two forms. The first is addressed by experimental tests of whether levels and types of guardianship in action influence crime levels, such as conducting experiments where guardianship is the manipulated treatment condition. This type of research is not without difficulties, as the occurrence of crime (the dependent variable) is out of experimental control, therefore, such studies could be difficult and time-consuming to perform. This could perhaps be the reason why there are no studies of this kind in the literature.

The second form of field test of guardianship is seen in studies where the active exercising of guardianship is the dependent variable. These studies use a staged attempt of a crime in an almost natural setting where the outcome measure is whether or not subjects (potential guardians) monitor or intervene in the attempted crime event. This set-up follows the lead of Latané and Darley's classic social psychological studies on helping behavior [26]. This research staged an event where helping behavior of naturally present bystanders was elicited in a situation where a person (acting in cooperation with researchers) seemed in urgent need of assistance, but not because this person was at risk of becoming a crime victim. They coined the term "bystander effect," and showed that the likelihood of a bystander intervening is a function of the number of other bystanders present (see also [29]).

There were several studies carried out in the 1970s and 1980s related to the bystander intervention research, where the staged event was an attempt to commit a crime rather than an individual needing urgent assistance. Some of these studies observed the rates of intervention in a fixed condition while others manipulated the conditions in the 
experiment. The conditions, thus, were either merely staging the crime event or augmenting the staging of the crime event with exhortations to intervene either by actors who made various comments on what occurred or by the presence of formal guardians at some distance. Other research has examined the effect of an appeal to prospective guardians (by mass media or through signs installed in the study locations) on intervention rates (i.e., [59]). We find that these studies are outside of the scope of the current discussion.

The staged crime attempt studies featured various crime types. The majority of these studies featured attempts at property crime (such as theft and shoplifting), but also attempted rapes $[1,9,17,20,22,32,38,42,43,44,47$; see also 15]. The results varied across these studies with rather low spontaneous intervention rates that ranged from $0 \%$ to $40 \%$, and observed provoked intervention rates that were higher, occasionally reaching $100 \%$. It seems fair to state that this line of research has not sketched a clear picture of the complex effect of the mutually interacting situational factors, crime type, number of bystanders, and provocation on the likelihood of intervention.

A common problem with the validity of these experiments is that the criminal actors did not react - contrary to what is expected based on routine activities theory - to the presence of others, more specifically, not reacting to being seen by bystanders. Routine activity theory [7] would predict that this made the actors behaviors inconsistent with what is expected in real-life, making the situation out of the normal for would-be guardians, perhaps making them ill-at-ease when contemplating intervention. Furthermore, the presence of (sometimes) rather large numbers of other bystanders (a condition which was often not experimentally controlled) will have lowered intervention 
rates. Winkel [59] observed that it is usually unclear in these experiments whether the prospective interveners have even observed the incident or classified it as an impending crime. This is a rather devastating criticism, as we know from Reynald's findings [36] that it is more the presence of a guardian than his or her actions that deter crime.

\section{DISCUSSION AND CONCLUSIONS}

Routine activities theory has inspired a great deal of research on victims/target suitability and offender motivation. The third element of the theory - capable guardianship - has not received as much attention. We set out to critically review the most up-to-date literature on guardianship with two main foci: (1) to review the way guardianship has been operationalized and measured, and (2) to review experimental and quasiexperimental evaluations and field tests of guardianship.

Two fundamental assumptions are important to Felson's thinking about guardianship: (1) the most important tasks for guardians are availability and monitoring, and (2) it is the idea that someone is watching and could detect problematic behaviors or people that deters the likely offender from committing a criminal act. Recent research on guardianship has elaborated on the nature of guardianship to include three types of controllers: place managers (who control space and place), handlers (who control the behavior of potential offenders), and target-guardians (who control potentially suitable targets) $[10,11,13,39,50]$. Most recently, Sampson et al. [39] further elaborated on the controller concept, indicating that there is a group of people or organizations who provide incentives for controllers to engage in controlling activities. They called them supercontrollers. 
As discussed above, we find that these elaborations do not adequately incorporate the unintentional and occasional guardians who are, arguably, the most important guardians in preventing crimes. We argue for a movement toward a formal definition that includes formal guardians, handlers, managers, and target-guardians, where a guardian is any and every person on the scene of a potential crime who might notice and intervene (whether they intend to or not). It is through mere presence that this guardian deters criminal activity.

Research on guardianship is often focused on of residential areas and tends to ignore public space. There is further confusion in guardianship research in differentiating between target suitability/hardening measures and measures of guardianship. The measurement and operationalization of guardianship in recent research (e.g., $[36,37])$ demonstrates a promising movement toward the use of observational data. This data is more ecologically valid and allows further elaboration of the guardianship process.

The methods used to examine guardianship have typically relied on macrostructural and survey data. The research designs are usually cross-sectional, relying on correlational analysis techniques and non-observational research methodologies. There is a distinct lack of quasi-experimental and experimental research designs in guardianship research.

The evaluative literature on guardianship interventions shows some promise. Actively monitored CCTV and neighborhood watch are the most well developed guardianship measures that are in current use. The weight of the evidence suggests that the use of security guards is a promising guardianship technique when implemented in car parks and targeted at vehicle crimes. The guardianship technique of place managers 
appears to be of unknown effectiveness in preventing crime in public places at the present time.

Theoretical Implications

There is a need for a clear definition of guardianship to clarify the guardianship construct. There is also a need for a theoretical elaboration of what the guardianship process entails and how exactly guardianship occurs. Reynald's $[36,37]$ work takes important steps toward this needed elaboration, but much more is needed. Finally, there is a clear need to further conceptualize and clarify what controllers and super controllers do and what the concepts mean. It is currently unclear when an individual or organization might be acting as one type of controller and when they might be another. There is a need to test if these three classifications of controllers are conceptually distinct from one another in practice.

\section{Research Implications}

Guardianship is currently an under-researched component of routine activity theory. More research is needed on the guardianship aspect of routine activities in general. There is a specific need for theoretical field tests and natural experiments of guardianship. The evaluative literature shows a movement toward more rigorous designs, but there is room for improvement.

One of the key benefits of the use of experimental and quasi-experimental methods is the ability to produce a high degree of confidence in the observed effects. This is ultimately achieved through greater control of extraneous factors or threats to validity. 
It is important to move from correlation closer to causality; this is what well-executed and high quality research designs allow. The experiment compared to survey data, for example, "attempts to demonstrate causality directly by building sufficient control into the design so that predicted outcomes can be observed at first hand" [in: [23]: 49).

In conclusion, it may be argued that the most important contribution that guardianship experiments — such as those outlined above - can make to criminological knowledge is clarifying the causal mechanisms underlying the relationship between guardianship and crime. Despite increasing attention to empirical tests of guardianship, the weakness of this body of research remains the void in empirical evidence demonstrating that high levels of guardianship can lead to lower crime levels. This causal link has been taken for granted, when in fact few studies have explicitly tested this or provided evidence that this is representative of empirical reality. Moreover, some studies have reported evidence that calls this assumption into question (e.g., [28]). Examining this causal link is a critical next step to advancing knowledge in this area.

\section{Acknowledgments}

We are grateful to the editor and the anonymous reviewers for helpful comments. 


\section{REFERENCES}

1. Austin, W. (1979). Sex differences in bystander intervention in a theft. Journal of Applied Social Psychology, 11, 2110-2120.

2. Barclay P., Buckley J., Brantingham P.J., et al. (1996). Preventing auto theft in suburban Vancouver commuter lots: Effects of a bike patrol. In R.V. Clarke (ed.), Preventing Mass Transit Crime. Crime Prevention Studies, vol. 6. (pp. 133-161). Monsey, NY: Criminal Justice Press.

3. Bennett, T.H., Holloway, K., \& Farrington, D.P. (2006). Does neighborhood watch reduce crime? A systematic review and meta-analysis. Journal of Experimental Criminology, 2(4), 437-458.

4. Block, R. \& Skogan, W.G. (1984). The Dynamics of Violence Between Strangers: Victim Resistance and Outcomes in Rape, Assault, and Robbery. Evanston, IL: Northwestern University.

5. Bowers, K.J. \& Johnson, S.D. (2006). Implementing failure and success: Some lessons from England. In J. Knutsson \& R.V. Clarke (eds.), Putting Theory to Work: Implementing Situational Crime Prevention and Problem-Oriented Policing, Crime Prevention Studies, Vol. 20. (pp. 163-198). Monsey, NY: Criminal Justice Press.

6. Brantingham, P.J. \& Brantingham, P.L. (1981). Environmental Criminology. Prospect Heights, IL: Waveland Press.

7. Cohen, L.E. \& Felson, M. (1979). Social change and crime rate trends: A routine activity approach. American Sociological Review, 44(4), 588-608.

8. Coupe, T. \& Blake, L. (2006). Daylight and darkness targeting strategies and the risks of being seen at residential burglaries. Criminology, 44(2), 431-464.

9. Dertke, M.C., Penner, L.A., Ulrich, K. (1974). Observer's reporting of shoplifting as a function of thief's race and sex. Journal of Social Psychology, 94, 213-221

10. Eck, J.E. (1994). Drug Markets and Drug Places: A Case-Control Study of the Spatial Structure of Illicit Drug Dealing. Unpublished Ph.D. dissertation. College Park, MD: University of Maryland.

11. Felson, M. (1995). Those who discourage crime. In J.E. Eck \& D. Weisburd (eds.), Crime and Place: Crime Prevention Studies, vol. 4. (pp. 53-66). Monsey, NY: Criminal Justice Press.

12. Felson, M. (2006). Crime and Nature. Thousand Oaks, CA: Sage. 
13. Felson, M. \& Boba, R. (2010). Crime and Everyday Life: Insight and Implications for Society. Thousand Oaks, CA: Pine Forge Press.

14. Felson, M. \& Cohen, L.E. (1980). Human ecology and crime: A routine activity approach. Human Ecology, 8(4), 389-406.

15. Fischer, P., Greitemeyer, T., Pollozek, F., et al. (2006). The unresponsive bystander: Are bystanders more responsive in dangerous emergencies? European Journal of Social Psychology, 36, 267-278.

16. Garofalo, J. \& Clark, D. (1992). Guardianship and residential burglary. Justice Quarterly, 9(3), 443-463.

17. Gelfand, D., Hartmann, D., Walder, P. \& Page, B. (1973). Who reports Shoplifters? A field experimental study. Journal of Personality and Social Psychology, 25(2), 276285.

18. Gill, M. \& Spriggs, A. (2005). Assessing the Impact of CCTV. Home Office Research Study, No. 292. London, UK: Home Office.

19. Gottfredson, M.R. \& Hirschi, T. (1990). A General Theory of Crime. Stanford, CA: Stanford University Press.

20. Harari, H., Harari, O., \& White, R. (1985). The reaction to rape by American male bystanders. The Journal of Social Psychology, 125, 653-658.

21. Hesseling, R. (1995). Theft from cars: Reduced or displaced? European Journal on Criminal Policy and Research, 3(3), 79-92.

22. Hindelang, M.J., Gottfredson, M.R., \& Garofalo, J. (1978). Victims of Personal Crime: An Empirical Foundation for a Theory of Personal Victimization. Cambridge, MA: Ballinger.

23. Jupp, V. (1989). Methods of Criminological Research. New York, NY: Routledge.

24. Kenney, D.J. (1986). Crime on the subways: Measuring the effectiveness of the guardian angels. Justice Quarterly, 3, 481-496.

25. Knutsson, J. (2006). What is there to gain? A case study in implementing without self-interest. In J. Knutsson \& R.V. Clarke (eds.), Putting Theory to Work: Implementing Situational Crime Prevention and Problem-Oriented Policing, Crime Prevention Studies, vol. 20. (pp. 89-110). Monsey, NY: Criminal Justice Press.

26. Latané, B. \& Darley, J. (1970). The Unresponsive Bystander: Why Doesn't He Help? New York: Appleton-Century-Crofts. 
27. Laycock, G. (2006). Implementing crime reduction measures: Conflicts and tensions. In J. Knutsson \& R.V. Clarke (eds.), Putting Theory to Work: Implementing Situational Crime Prevention and Problem-Oriented Policing, Crime Prevention Studies, vol. 20. (pp. 65-88). Monsey, NY: Criminal Justice Press.

28. Lynch, J.P. \& Cantor, D. (1992). Ecological and behavioral influences on property victimization at home: Implications for opportunity theory. Journal of Research in Crime \& Delinquency, 29(3), 335-362.

29. Manning, R., Levine, M., \& Collins, A. (2007). The Kitty Genovese murder and the social psychology of helping: The parable of the 38 witnesses. American Psychologist, 62(6), 555-562.

30. Miethe, T.D., Stafford, M.C., \& Sloane, D. (1990). Lifestyle changes and risks of criminal victimization. Journal of Quantitative Criminology, 6(4), 357-376.

31. Miethe, T.D. \& Meier, R.F. (1994). Crime and its Social Context: Toward an Integrated Theory of Offenders, Victims and Situations. Albany: State University of New York Press.

32. Moriarty, T. (1975). Crime, commitment and the responsive bystander: Two field experiments. Journal of Personality and Social Psychology, 31(2), 270-376.

33. Mustaine, E.E. \& Tewksbury, R. (1998). Predicting risks of larceny theft victimization: A routine activity analysis using refined lifestyle measures. Criminology, $36,829-858$.

34. Pennell, S., Curtis, C., Henderson, J., et al. (1989). Guardian Angels: A unique approach to crime prevention. Crime and Delinquency, 35, 378-400.

35. Poyner, B. (1991). Situational crime prevention in two parking facilities. Security Journal, 2(2), 96-101.

36. Reynald, D.M. (2009). Guardianship in action: Developing a new tool for measurement. Crime Prevention and Community Safety, 11(1), 1-20.

37. Reynald, D.M. (2010). Guardians on guardianship: Factors affecting the willingness to supervise, the ability to detect potential offenders and the willingness to intervene. Journal of Research in Crime \& Delinquency, 47(3), 358-390.

38. Roell, G. van Dijk, J.M. and Steinmetz, C.H.D. (1982). Interventiegedrag door omstanders: een veldexperiment. Tijdschrift voor Criminologie, 1, 21-35.

39. Sampson, R., Eck, J.E., \& Dunham, J. (2010). Super controllers and crime prevention: A routine activity explanation of crime prevention success and failure. Security Journal, 23(1), 37-51. 
40. Sampson, R.J. (2010). Gold standard myths: Observations on the experimental turn in quantitative criminology. Journal of Quantitative Criminology, 26(4), 489-500.

41. Sampson, R.J., Raudenbush, S.W., \& Earls, F. (1997). Neighborhoods and violent crime: A multilevel study of collective efficacy. Science, 277(5328), 918-924.

42. Schwartz, L., Jennings, K., Petrillo, J., Kidd, R. (1980). Role of commitments in the decision to stop a theft. Journal of Social Psychology, 110, 183-192.

43. Schwartz, S. \& Gottlieb, A. (1976). Bystanders reactions to a violent theft: Crime in Jerusalem. Journal of Personality and Social Psychology, 34(6), 1188-1199.

44. Shaffer, D.R., Rogel, M, Hendrick, C. (1975). Intervention in the library: the effect of increased responsibility on bystander's willingness to prevent a theft. Journal of Applied Social Psychology, 5(4), 303-319.

45. Sklansky, D.A. (2008). Democracy and the Police. Stanford, CA: Stanford University Press.

46. Stahura, J.M. \& Sloan, J.J. (1988). Urban stratification of places, routine activities and suburban crime rates. Social Forces, 66(4), 1102-1118.

47. Takooshian, H. \& Bodinger, H. (1982). Bystander indifference to street crime. In L. Savitz \& N. Johnston (eds.), Contemporary Criminology, (pp. 209-216). New York: John Wiley \& Sons Inc.

48. Tewksbury, R. \& Mustaine, E.E. (2003). College students' lifestyles and selfprotective behaviors: Further considerations of the guardianship concept in routine activity theory. Criminal Justice and Behavior, 30(3), 302-327.

49. Tilley, N. \& Webb, J. (1994). Burglary Reduction: Findings from Safer Cities Scheme. Crime Prevention Unit Paper 51. London: Home Office.

50. Tillyer, M.S. \& Eck, J.E. (2010). Getting a handle on crime: A further extension of routine activities theory. Security Journal. Online First edition, doi: 10.1057.sj.2010.2.

51. Tseloni, A., Wittebrood, K., Farrell, G., et al. (2004). Burglary victimization in England and Wales, the United States, and the Netherlands: A cross-national comparative test of routine activities and lifestyle theories. British Journal of Criminology, 44(1), 6191.

52. van Andel, H. (1989). Crime prevention that works: The care of public transport in the Netherlands. British Journal of Criminology, 29(1), 47-56. 
53. Weisburd, D. (2010). Justifying the use of non-experimental methods and disqualifying the use of randomized controlled trials: Challenging the folklore in evaluation research in crime and justice. Journal of Experimental Criminology, 6, 209227.

54. Welsh, B.C. \& Farrington, D.P. (2009a). Public area CCTV and crime prevention: An updated systematic review and meta-analysis. Justice Quarterly, 26(4), 716-745.

55. Welsh, B.C. \& Farrington, D.P. (2009b). Making Public Places Safer: Surveillance and Crime Prevention. New York: Oxford University Press.

56. Welsh, B.C., Mudge, M.E., \& Farrington, D.P. (2010). Reconceptualizing public area surveillance and crime prevention: Security guards, place managers and defensible space. Security Journal, 23(4), 299-319.

57. Wilcox, P., Madensen, T.D., \& Tillyer, M.S. (2007). Guardianship in context: Implications for burglary victimization, risk and prevention. Criminology, 45(4), 771803.

58. Winge, S. \& Knutsson, J. (2003). An Evaluation of the CCTV Scheme at Oslo Central Railway Station. Crime Prevention and Community Safety, 5(3), 49-59.

59. Winkel, F.W. (1981). Sociopreventie. De rol van omstanders bij de totstandkoming van een delict. Tijdschrift voor Criminologie, 1, 53-71. 
Table 1

Summary of Guardianship and Crime Studies

\begin{tabular}{|c|c|c|c|}
\hline $\begin{array}{l}\text { Author and } \\
\text { Publication Date }\end{array}$ & $\begin{array}{l}\text { Measurement of } \\
\text { Guardianship }\end{array}$ & Methodology & Main Finding \\
\hline $\begin{array}{l}\text { Cohen \& Felson } \\
\text { (1979) }\end{array}$ & $\begin{array}{l}\text { Labor force } \\
\text { participation, single } \\
\text { adult households }\end{array}$ & Macro-structural & $\begin{array}{l}\text { Guardianship related } \\
\text { to a reduction in } \\
\text { crime }\end{array}$ \\
\hline $\begin{array}{l}\text { Coupe \& Blake } \\
(2006)\end{array}$ & $\begin{array}{l}\text { Security devices, } \\
\text { detection of burglar, } \\
\text { occupancy of } \\
\text { dwelling at time of } \\
\text { burglary }\end{array}$ & $\begin{array}{l}\text { Surveys of police } \\
\text { officers, victims, } \\
\text { and incident sites, } \\
\text { and police records }\end{array}$ & $\begin{array}{l}\text { Guardianship } \\
\text { operated } \\
\text { conditionally on } \\
\text { daylight or darkness }\end{array}$ \\
\hline $\begin{array}{l}\text { Garofalo \& Clark } \\
\text { (1992) }\end{array}$ & $\begin{array}{l}\text { Household members } \\
\text { home, presence of a } \\
\text { dog or alarm system }\end{array}$ & $\begin{array}{l}\text { Cross-sectional } \\
\text { household survey }\end{array}$ & $\begin{array}{l}\text { Effect of } \\
\text { guardianship on } \\
\text { residential burglary } \\
\text { underestimated in } \\
\text { prior research }\end{array}$ \\
\hline $\begin{array}{l}\text { Lynch \& Cantor } \\
\text { (1992) }\end{array}$ & $\begin{array}{l}\text { Time spent in the } \\
\text { house during day } \\
\text { light and evening, } \\
\text { neighbors watching } \\
\text { houses }\end{array}$ & $\begin{array}{l}\text { National Crime } \\
\text { Victimization } \\
\text { Survey and victim } \\
\text { risk supplement }\end{array}$ & $\begin{array}{l}\text { Guardianship at } \\
\text { block level and } \\
\text { daytime occupancy } \\
\text { had significant effect } \\
\text { on burglary risk }\end{array}$ \\
\hline $\begin{array}{l}\text { Miethe et al. } \\
\text { (1990) }\end{array}$ & $\begin{array}{l}\text { Household occupancy } \\
\text { based on number of } \\
\text { individuals over age } \\
12\end{array}$ & $\begin{array}{l}\text { British Crime } \\
\text { Survey }\end{array}$ & $\begin{array}{l}\text { Proximity and } \\
\text { exposure were } \\
\text { stronger predictors } \\
\text { than guardianship } \\
\text { and design } \\
\text { attractiveness }\end{array}$ \\
\hline $\begin{array}{l}\text { Mustaine \& } \\
\text { Tewksbury (1998) }\end{array}$ & $\begin{array}{l}\text { Self-protective } \\
\text { behaviors (e.g., } \\
\text { weapons possession) }\end{array}$ & $\begin{array}{l}\text { Cross-sectional, } \\
\text { self-administered } \\
\text { survey of college } \\
\text { students }\end{array}$ & $\begin{array}{l}\text { Guardianship had a } \\
\text { significant effect on } \\
\text { crime }\end{array}$ \\
\hline $\begin{array}{l}\text { Reynald (2009; } \\
\text { 2010) }\end{array}$ & $\begin{array}{l}\text { Presence and } \\
\text { interventions by } \\
\text { guardians }\end{array}$ & Field observations & $\begin{array}{l}\text { Guardianship had a } \\
\text { significant effect on } \\
\text { crime }\end{array}$ \\
\hline $\begin{array}{l}\text { Stahura \& Sloan } \\
\text { (1988) }\end{array}$ & $\begin{array}{l}\text { Police employment, } \\
\text { police expenditure, } \\
\text { female labor force } \\
\text { nonparticipation }\end{array}$ & $\begin{array}{l}\text { Macro-structural; } \\
\text { cross-sectional, } \\
\text { aggregated data }\end{array}$ & $\begin{array}{l}\text { Guardianship had a } \\
\text { significant effect on } \\
\text { crime }\end{array}$ \\
\hline $\begin{array}{l}\text { Tewksbury \& } \\
\text { Mustaine (2003) }\end{array}$ & $\begin{array}{l}\text { Self-protective } \\
\text { behaviors (e.g., } \\
\text { weapons possession) }\end{array}$ & $\begin{array}{l}\text { Cross-sectional, } \\
\text { self-administered } \\
\text { survey of college } \\
\text { students }\end{array}$ & Crime not measured \\
\hline Tseloni et al. & Household & National Crime & Guardianship had a \\
\hline
\end{tabular}




\begin{tabular}{|l|l|l|l|}
\hline (2004) & $\begin{array}{l}\text { composition and } \\
\text { occupancy, neighbors } \\
\text { watching house, use } \\
\text { of self-protection } \\
\text { measures, collective } \\
\text { crime prevention } \\
\text { enterprises }\end{array}$ & $\begin{array}{l}\text { Victimization } \\
\text { Survey, British } \\
\text { Crime Survey, } \\
\text { Police Monitor }\end{array}$ & $\begin{array}{l}\text { significant effect on } \\
\text { crime }\end{array}$ \\
\hline $\begin{array}{l}\text { Wilcox et al. } \\
(2007)\end{array}$ & $\begin{array}{l}\text { Individual-level } \\
\text { target hardening, } \\
\text { place management } \\
\text { and surveillance; } \\
\text { neighborhood-level } \\
\text { target hardening, } \\
\text { informal social } \\
\text { control, natural } \\
\text { surveillance }\end{array}$ & $\begin{array}{l}\text { Cross-sectional } \\
\text { neighborhood } \\
\text { survey }\end{array}$ & $\begin{array}{l}\text { Individual-level: } \\
\text { target hardening, } \\
\text { place management, } \\
\text { surveillance related } \\
\text { more negatively to } \\
\text { burglary with } \\
\text { increased } \\
\text { neighborhood-level } \\
\text { target hardening, } \\
\text { informal social } \\
\text { control, natural } \\
\text { surveillance }\end{array}$ \\
\hline
\end{tabular}

